УДК 339.177(004.9)

\title{
THE CONSUMER VALUE OF GOODS IN THE CONTEXT OF THE DIGITALIZATION OF THE ECONOMY ${ }^{\star}$
}

\author{
Vitalina Babenko \\ Doctor of Economic Sciences, Ph.D (Technical Sciences), Professor \\ V.N. Karazin Kharkiv National University \\ Svobody sq., 4, Kharkiv, Ukraine, 61022 \\ e-mail: vitalinababenko@karazin.ua \\ ORCID: https://orcid.org/0000-0002-4816-4579 \\ Scopus Author ID: 56658371300 \\ Hanna Fedorova \\ Lecturer \\ V. N. Karazin Kharkiv National University \\ 4, Svobody sq., Kharkiv, Ukraine, 61022 \\ e-mail: g.y.fedorova@karazin.ua \\ Boris Pokhodenko \\ V.N. Karazin Kharkiv National University \\ Svobody sq., 4, Kharkiv, Ukraine, 61022 \\ E-mail: boris.pokhodenko@karazin.ua \\ ORCID: https:/ / orcid.org/0000-0002-9995-7077
}

\begin{abstract}
The object of the research is the consumer value of a product as the basis for the quality of an enterprise's products in the context of the digitalization of the economy. The purpose of the work is to formulate a set of recommendations for increasing the consumer value of the product on the basis of research and assessment of the consumer value of the product as the basis for product quality. The research methods are based on three main approaches: monetary, non-monetary and synthetic. In the course of the study, the methodological foundations of the formation of the consumer value of products were considered, the influence of the consumer value on the quality of products was investigated, the consumer value of products was analyzed in the context of the digitalization of the economy. As a result of the study, practical recommendations and measures were developed to increase the consumer value of products in the context of the digitalization of the economy. The results of the study are to develop a set of measures to improve the production process of the enterprise in order to increase the quality of products by increasing consumer value in the context of the digitalization of the economy. Research prospects: it is planned to study more deeply the problems of interaction between product quality and consumer value, develop a complex and a program to increase the consumer value of products in the context of the digitalization of the economy.
\end{abstract}

Keywords: consumer value, digitalization of the economy, market entities, enterprise of market, consumer market.

Introduction. In a modern market, the consumer value of a product can be directly considered as one of the important regulators of product quality in the market for goods and services provided by various enterprises. Today on the market there is a huge number of all kinds of products with very different prices, it would seem, for the same goods. At the same time, equal prices for goods, obviously, from the point of view of the buyer, do not correspond to these prices. Each of the consumers gives preference to the product that is of the greatest value to him. In the other words, as F. Kotler [11] notes "seeks to maximize value", starting from his idea of the product quality, its value and all kinds of costs for its operation. Thus, it can be concluded that the consumer value of the product is not equal for all buyers, it is individualized for each of the consumers. However, basically, in accordance with the laws of mathematical statistics, the average established market value of a product is almost always close to its true consumer value.

In the current conditions of digitalization of the economy, many enterprises are faced with rather tough competition in their trade, which every year more and more takes place. The bulk of the leading Western companies have moved from a "product and marketing philosophy" to a "consumer and marketing philosophy." Leading companies are focusing tremendous attention on the study and

\footnotetext{
"Cite as: Babenko, V., Fedorova, H., Pokhodenko, B. (2021). The Consumer Value of Goods in the Context of the Digitalization of the Economy, The Journal of V. N. Karazin Kharkiv National University. Series: International Relations. Economics. Country Studies. Tourism. 13, 38-49. https://doi.org/10.26565/2310-9513-2021-13-04
} 
satisfaction of consumer needs. In order to deserve a high place in the modern market, enterprises simply need to provide their consumers with any value, as a product or service, thereby providing the consumer with the best and highest quality product. However, this is not always enough, in addition to the above, it is necessary to form in the consumer a certain concept of the importance of the goods, which will be associated with the enterprise itself or the products that it produces.

Materials and Methods. The purpose of the article is to formulate a set of recommendations for increasing the consumer value of a product in the context of the digitalization of the economy on the basis of research and assessment of the consumer value of a product as the basis for product quality.

In accordance with the above goal, the following tasks were identified during the study:

1. Consideration of the theoretical foundations of the formation of the consumer value of the product and its methodology.

2. Analysis of the ways and methods of influence of enterprises on the formation of consumer value in the context of the digitalization of the economy.

3. Assessment of product quality by assessing the consumer value of a product in the context of digitalization of the economy.

The theoretical basis of the study was the works of domestic and foreign researchers, specialists in the field of product quality, the foundations of digitalization of the economy.

While conducting a study of the consumer value of a product as the basis for product quality, three main approaches were studied: monetary, nonmonetary and synthetic, combining elements of the two previous ones. During the study, it became clear that the most suitable for analyzing and assessing the consumer value of a product in the context of the digitalization of the economy is a nonmonetary approach. In practice, one of the main and frequently used methods of the non-monetary approach, the Kano method, was applied.

The concept and essence of the digital economy. The concept and essence of the digital economy. Don Tapscott, a Canadian entrepreneur, consultant and CEO of Tapscott Group, is considered to be the "father of the digital economy [13]." Published in 1994, his book "Digital Economy" became the first book to describe the system of a virtual economic system. The digital economy can be viewed from a variety of perspectives. In our opinion, the digital economy is: - a type of economy characterized by the active introduction and practical use of digital technologies for collecting, storing, processing, transforming and transmitting information in all spheres of human activity; - a system of socioeconomic and organizational-technical relations based on the use of digital information and telecommunication technologies; is a complex organizational and technical system in the form of a set of various elements (technical, infrastructural, organizational, software, regulatory, legislative, etc.) with distributed interaction and mutual use by economic agents for the exchange of knowledge in conditions of permanent development. The key in defining a digital system is the exchange of knowledge, the technologies that enable it, and the people who are able to participate in and manage this exchange $[5,10]$.

In many countries, considerable attention is paid to the formation of a digital society, which is confirmed by the adopted strategies / programs for the development of the digital economy, including [11-15]: 2000 - Denmark, 2005 - Singapore, 2008 - Australia, Hong Kong, Great Britain, New Zealand, 2009 - the European Union as a whole, 2010 - Canada, 2012 - Malaysia, 2013 - South Korea, 2015 - India, Kazakhstan.

It is estimated that the share of the digital economy in the GDP of the world's largest countries in 2030 will reach 50-60\%. In Ukraine, this figure, according to the Ukrainian Institute of the Future, may be even higher - 65\% of GDP (for the implementation of the forced scenario of digital economy in Ukraine) [16]. Digitalization is one of the main factors in the growth of the world economy in the next 5-10 years. In addition to the direct productivity gains that companies receive from digital technologies, there is a chain of indirect benefits of digitalization, such as saving time, creating new demand for new products and services, new quality and value, and so on.

Digitalization will be the main tool to achieve Ukraine's strategic goal - to increase GDP by 8 times, up to 1 trillion dollars. in 2030E, and ensuring the well-being, comfort and quality of life of Ukrainians at a level higher than the European average [16].

Problems that hinder the development of digital trends in Ukraine and the transformation of the Ukrainian economy into digital [1, 7]:

\section{Institutional}

- Low involvement of state institutions in the implementation of the Concept of Digital Economy and Society Development (Digital Agenda of Ukraine)

- Inconsistency of the profile legislation with global challenges and opportunities (progressive developed bills have not yet become laws)

- Inconsistency of national, regional, sectoral strategies and development programs with digital opportunities.

\section{Infrastructure}

- Low level of coverage of the country's territory by digital infrastructures (for example, the EU's goal by $2020 \mathrm{E}$ to cover $100 \%$ of the territory with broadband Internet access, in Ukraine this figure is about $60 \%$ )

- Lack of separate digital infrastructures (for example, Internet of Things infrastructure, electronic identification and trust, etc.). 
Unequal access of citizens to digital technologies and new opportunities (digital divide).

3. Ecosystem.

- Weak state policy on incentives and incentives for the development of innovative economy.

- Immature investment capital market.

Outdated education system, teaching methods, lack of focus on STEM-education, soft skills and entrepreneurial skills, imperfect models of technology transfer and consolidation of knowledge and skills.

- Shortage of highly qualified personnel for the full development of the digital economy and digitalization in general.

4. In the field of e-government and governance ("state in a smartphone")

- Low level of automation and digitalization of public services due to weak motivation of government agencies (there is no full understanding of the potential benefits of total digitalization).

The main goals of the national Program "Digital Economy" are as follows: increasing the involvement of citizens and business entities from working in the digital space; creation of an infrastructure that ensures the interaction of subjects in the digital space; the emergence of sustainable digital ecosystems for business entities; reducing the costs of business entities and citizens when interacting with the state and among themselves; increasing the competitiveness of the economy, business entities and citizens through digital transformations in all spheres of society's life The target indicators for the development of the digital economy are the following $[4,5,11]$ : the share of online commerce in GDP is at least 5\% (current value $2.4 \%$ ); the share of the digital economy in GDP is at least $20 \%$ (current value is $11 \%$ ); the share of people employed in the high-tech digital segment of the economy; the total capitalization of companies in the digital technology sector; share of exports of digital goods and services, as well as exports of traditional goods and services through digital channels in total exports.

The main components of the digital economy today are consumption / e-commerce, investment in development, public administration, exportimport activities. The largest share in the total volume of the digital economy is consumption as a form of virtual commerce. In recent years, the share of e-commerce has grown by $35-40 \%$, in the total volume of retail sales it is about $5 \%$, but still very small compared to the G20 countries [3,9]. Virtual commerce is most widespread in the segments of household appliances and electronics, clothing and footwear, furniture and household goods. These categories account for $80 \%$ of the global e-commerce market. The market for virtual food products is also actively developing, especially in large cities. The most important instrument of the economic system, including the digital economy, is money, which has undergone a significant evolution in its development.

\section{Consumer value of goods.}

Today on the market there is a large number of various products (goods and brands) with very different prices for seeming (to the buyer) identical goods and at the same time the same prices for goods, which obviously, in the buyer's opinion, do not correspond to these prices [1, 3]. Each consumer chooses the product that is of the greatest value to him, based on his idea of the quality of the product, its price and possible operating costs. It turns out that the consumer value of a product is not the same for all buyers, it is highly individualized, although in its mass, according to the laws of mathematical statistics, the weighted average market value of a product always approaches its true consumer value [4].

So what are the factors that determine the value of a product? The consumer value of a product depends not only on the performance indicators of quality, but also on a number of other consumer values that directly or indirectly characterize the product.

All consumer values can be conditionally classified into several categories that differ from each other by temporary factors of action: basic, permanent, temporary values, accompanying, introduced, universal [6].

Basic values are consumer values embedded in the product at the design stage and characterized by performance indicators of quality, which include indicators of purpose (functional), reliability (reliability, durability, maintainability, preservation), technical aesthetics (composition integrity, perfection marketable), environmental (physical, chemical, microbiological), ergonomic (compliance with ergonomic requirements in the working area), patent law (patent purity, patent protection), safety and portability.

The listed indicators characterize the product throughout its entire life cycle. They can be improved, changed, but their initial nomenclature does not change. These indicators define the basic consumer quality, which is the basis for comparison with competitors' products.

The basic values include the cost of production, which characterizes the production and technological base of the manufacturer and its resource potential. The cost of manufacturing products is actually the sum of the costs of creating and selling products with specified basic quality indicators, i.e. there is a high correlation between the basic quality of the product and the cost of its manufacture.

Permanent, temporary, concomitant and introduced consumer values complement the basic ones. Additional values do not change the basic quality inherent in product design, but enhance or shade its effect in the eyes of the consumer, which is expressed in an increase in the consumer value of the product. 
Permanent values are such additional consumer values that operate throughout the entire life cycle of a product, but are not directly related to the basic values, but indirectly. For example, the image of the manufacturer of the products, the prestige of the store, the certificate for the quality system, the popularity of the brand, etc. These values have different ratings [8]. Their impact on the buyer can significantly increase the consumer value of the product. In some cases, the influence of only these values ensures long-term liquidity of products, even if they are inferior to competitors in terms of basic indicators. A firm's image, for example, also acts as a signature of a famous artist.

Temporary values are additional values that are directly related to the type and quality of products, but act temporarily, sometimes seasonally, usually less than the product's life cycle: novelty, fashion, prestige. These values, as a rule, keep the prices of the products hitting for a while. Ideally, when the life cycle of a product is commensurate with the duration of temporary values. Temporary values are realized by the potential possibility of a markup to the cost of goods, decreasing in time (due to its obsolescence).

Associated values are additional consumer values that are not directly related to the product, but facilitate or complicate the conditions for its purchase or operation: seasonal demand for products, inflation rate (for exported or imported goods). Associated values can both contribute to the liquidity of the product and make it difficult to sell it. The markup to products due to the action of accompanying values can fluctuate significantly over time.

Introduced values - informational values: advertising, exhibitions, contests, which in themselves do not have either direct or indirect relation to the product, but due to new or repeated information about the values related to the product, significantly increase its consumer value in the eyes of many buyers. Introduced values also include rumors, opinions, life experiences. The impact of the value added can be both temporary and permanent (eg advertising). The values introduced in time act in a similar way to the accompanying ones. The fluctuating nature of the mark-up is caused by the weakening in time of the impact of information activities (before its renewal).

Most of the products, as a rule, do not have additional consumer values. This is especially true for materials, semi-finished products, component parts, the value of which is professionally assessed by consumers according to basic characteristics, therefore, their value on the market can be predicted with a high probability even during the development period. Since additional values are expressed as a markup to the cost price, the share of this markup can be considered the profitability of the product due to a specific consumer value.
Universal values are the market value of a product or a price. Price is the main value, which, like a mirror, is adequate to consumer properties, but with some error caused by the stochastic nature of the dependence of price and quality. At the same time, the price, whatever the product, has a universal dimension (in monetary terms), i.e. it can be used to compare the value of products of different types and quality.

Successful promotion of a new product to the market will largely depend on the correct consideration of all factors affecting the liquidity of the product, and especially on the manufacturer's ability to identify or form additional consumer values that enhance the basic quality of the product.

So, from all of the above, we can conclude that quality indicators, which are the main category of consumer values, create a base (basis) for the formation of prices, the cost of production, depending on its initial quality. Based on the basic values (quality indicators), all subsequent values are formed that are part of the consumer value of the product. Only a few have no connection with basic values, they were noted above.

The quantitative characteristic of one or more properties of a product that make up its quality is called an indicator of product quality.

The high quality of products is predetermined by various factors, the main of which are [5]:

factors of a technical nature (constructive, technological, metrological, etc.);

- factors of an economic nature (financial, regulatory, material, etc.);

- factors of a social nature (organizational, legal, personnel, etc.).

- The set of product quality indicators can be classified according to the following criteria:

- $\quad$ - by the number of characterized properties (single, complex and integral indicators);

- $\quad$ - in relation to various properties of products (indicators of reliability, manufacturability, ergonomics, etc.);

- by the stage of determination (design, production and operational indicators);

- - by the method of determination (calculated, statistical, experimental, expert indicators);

- by the nature of use to assess the level of quality (basic and relative indicators);

- by the way of expression (dimensional indicators and indicators expressed in dimensionless units, for example, points, percentages).

A product quality indicator characterizing one of its properties is called a single product quality indicator (for example, power, fuel calorific value, etc.).

When applying the complex method, a complex quality indicator is used, which is determined by bringing together individual indicators using the 
weight coefficients of each indicator. In this case, the functional dependence can be used:

$$
\mathrm{K}=\mathrm{f}\left(\mathrm{n}, \mathrm{b}_{\mathrm{i}}, \mathrm{k}_{\mathrm{i}}\right), \quad \mathrm{i}=1,2,3, \ldots \ldots \ldots, \mathrm{n}_{\mathrm{i}},
$$

where $\mathrm{K}$ - complex indicator of product quality; $\mathrm{n}$ - number of indicators taken into account;

$\mathrm{b}_{\mathrm{i}}-$ the weighting factor of the i-th quality indicator; $\mathrm{k}_{\mathrm{i}}$-i-th quality indicator (single or relative).

The algorithm for calculating the complex quality indicator is shown in Fig. 1. To determine the nomenclature of quality indicators, weight coefficients and the type of functional dependence f, experimental-statistical and expert methods are used.

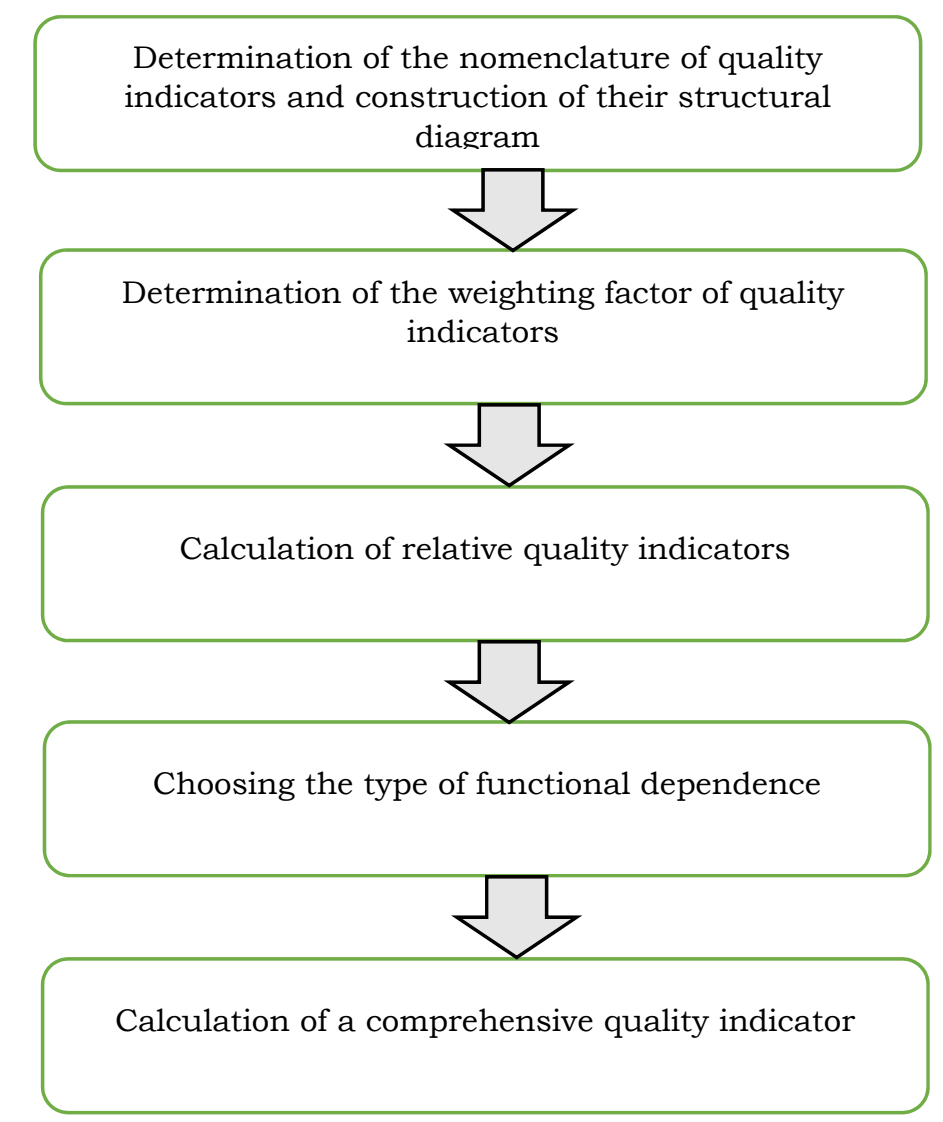

Fig. 1. Algorithm for calculating a complex quality indicator

Among the quality indicators, there are those that cannot be expressed in numerical values (shades, smell, timbre, etc.). They are determined using the senses (organoleptically) and are called sensory characteristics.

Assessment of the level of product quality can be carried out by differential or complex methods. When using the differential method, a comparison is made of single indicators of the quality of new products with identical basic quality indicators, and in the case of a complex method, actual complex indicators with basic complex indicators.

The numerical values of quality indicators are established using objective and subjective methods. Objective methods: measuring, registration and calculation. Subjective methods: organoleptic, sociological and expert. Objective methods are based on the use of technical measuring instruments, registration, counting events, performing calculations. The basis of subjective methods is the analysis of the perception of the human sense organs, the 42 collection and consideration of various opinions, decisions made by a group of expert experts.

There is establishes the following nomenclature of the main 10 groups of quality indicators according to the properties of products characterized by them [4]:

1. Indicators of purpose characterize the properties of the product, which determine the main functions for which it is intended, and determine the scope of its application.

This group includes:

a) classification indicators that establish the belonging of products to the classification group (vehicle classes, instrument accuracy, etc.);

b) functional (operational), characterizing the useful result from the operation of products (computer speed, mill productivity, measuring instrument accuracy, etc.);

c) constructive, giving an accurate idea of the main design solutions of products (diesel engines, gasoline, electric, etc.);

d) indicators of composition and structure that determine the content of chemical elements and

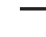


their compounds in products (percentage of sulfur and ash in coke, etc.). The indicators of this group play a major role in assessing the level of quality; they are often used as optimization criteria and are used in conjunction with other types of indicators.

2. Indicators of reliability characterize the properties of reliability, durability, maintainability and preservation.

Reliability - the property of a product to remain operational for some time or operating time.

Durability - the property of a product to maintain performance up to the limit state with the necessary breaks for maintenance and repair.

Maintainability is the ability of a product to undergo repair.

Preservation is the property of products and products to maintain a sound and consumable condition during the storage and transportation period specified in the technical documentation, as well as after it.

3. Ergonomic indicators characterize the "person - product" system and take into account the complex of human properties manifested in production and household processes. These include hygienic (illumination, temperature, pressure, humidity), anthropometric (clothes, shoes, furniture, control panels) and psychophysiological (speed and power capabilities, hearing thresholds, vision, etc.).

Psychophysiological characterizes the fitness of the product to the human sense organs.

Psychological characterizes the ability to perceive and process various information.

Physiological characterizes the permissible physical activity on various human organs.

4. Aesthetic indicators characterize information expressiveness, rationality of form, integrity of composition, perfection of production performance, stability of presentation (characteristics of artistic styles, shades, smells, harmony, etc.).

5. Manufacturability indicators characterize the properties of products that determine the optimal distribution of the costs of materials, time and means of labor in the technical preparation of production, manufacture and operation of products. These are indicators of labor intensity, material and capital intensity, the cost of products. Both general (total) and structural, specific, comparative or relative indicators are calculated.

6. Indicators of standardization and unification characterize the saturation of products with standard, unified and original parts, as well as the level of unification with other products.

The main indicators of unification are the coefficients of applicability, repeatability, mutual unification for product groups, the proportion of original parts (assemblies). All government and industry standard parts are standard.

7. Patent and legal indicators characterize the degree of updating of technical solutions used in products, their patent protection, as well as the possibility of unimpeded sale of products in our country and abroad (the number or proportion of patented or licensed parts (assemblies), etc.).

8. Environmental indicators characterize the level of harmful effects on the environment arising from the operation or consumption of products. For example, the content of harmful impurities released into the environment, the likelihood of the release of harmful particles, gases, radiation during storage, transportation and use of products, the MPC level.

9. Safety indicators characterize the features of a product that determine human safety during its operation or consumption. They reflect the requirements for the norms and means of protecting people in the area of possible danger in the event of an emergency, and are provided for by the system of state standards for labor safety, as well as international standards.

10. Economic indicators characterize the costs of development, manufacturing, operation or consumption of products, taken into account in the integral indicator of product quality (various types of costs, cost, price, etc.), when comparing various product samples - technical and economic indicators.

Table 1 shows an example of the use of some basic indicators for products that are consumed in use and consume their resource.

Measures to increase the consumer value of goods.

It is important for every seller that their product gets as much attention as possible. In order to achieve high demand for products, it is necessary to clearly understand the true needs of potential buyers. Only in the case when the manufacturer of the goods thinks not only about his own profit and profit, but also about the desires and needs of the buyer, a high demand and interest in the product is created. The growth and success of the company fully depend on how much the client's needs are taken into account and the quality of their satisfaction. If the organization's products do not meet the needs of the customer, or does not satisfy them insufficiently, then the flow of customers can either decrease, or it simply becomes insufficient to support the business. By choosing the right strategy and taking a series of measures, the company can not only justify the high price of its product, but also increase the perceived value of the product [13].

The consumer value of a product is the ratio between the benefits that the customer receives as a result of the purchase and use of the product and the cost of purchasing it. An increase in this indicator not only allows the organization to stay in its price category, but also in the long term, makes it possible to rise one step higher. For successful promotion in the modern market, an enterprise needs to clearly and economically justify the pricing of goods. The main and most 
important task in increasing the consumer value of a product is the identified economic benefit for the consumer. Initially, it is necessary to help the client find the reasons for the problems that he encountered at the stage of selection, and find solutions for them. In order to determine what still constitutes the greatest value in product characteristics and minimizes consumer risks, various approaches and methods have been created to assess and analyze the consumer value of a product. The formation of a strategy for increasing value implies a change in the emphasis of marketing policy from a product to a business process.

The main ways of developing the consumer value of the product are shown in Figure 2 [3].

Table 1

\section{Applicability of some indicators of product quality by type}

\begin{tabular}{|c|c|c|c|c|c|}
\hline \multirow[t]{2}{*}{$\begin{array}{l}\text { Product quality } \\
\text { indicators }\end{array}$} & \multicolumn{3}{|c|}{ Products consumable in use } & \multicolumn{2}{|c|}{$\begin{array}{l}\text { Products that consume their } \\
\text { resources }\end{array}$} \\
\hline & $\begin{array}{c}\text { Raw } \\
\text { materials } \\
\text { and } \\
\text { natural } \\
\text { fuels }\end{array}$ & $\begin{array}{l}\text { Materials } \\
\text { and } \\
\text { products }\end{array}$ & Consumables & $\begin{array}{l}\text { Repaired } \\
\text { products }\end{array}$ & $\begin{array}{l}\text { Non-repaired } \\
\text { products }\end{array}$ \\
\hline $\begin{array}{l}\text { Functional } \\
\text { suitability }\end{array}$ & + & + & + & + & + \\
\hline safety: & + & + & + & $(+)$ & $(+)$ \\
\hline reliability & - & - & $(+)$ & + & + \\
\hline durability & - & - & $(+)$ & + & + \\
\hline maintainability & - & - & $(+)$ & - & + \\
\hline persistence & + & + & + & + & $(+)$ \\
\hline Ergonomics & - & - & + & $(+)$ & $(+)$ \\
\hline Aesthetics & $(+)$ & $(+)$ & $(+)$ & $(+)$ & $(+)$ \\
\hline \multicolumn{6}{|l|}{ Manufacturability } \\
\hline in production & + & + & + & + & + \\
\hline In use & $(+)$ & $(+)$ & + & $(+)$ & + \\
\hline $\begin{array}{l}\text { Resource } \\
\text { consumption }\end{array}$ & - & - & - & $(+)$ & $(+)$ \\
\hline Security & $(+)$ & $(+)$ & $(+)$ & $(+)$ & $(+)$ \\
\hline $\begin{array}{l}\text { Environmental } \\
\text { friendliness }\end{array}$ & $(+)$ & $(+)$ & $(+)$ & $(+)$ & $(+)$ \\
\hline
\end{tabular}

sign "+" means applicability, sign "-" inapplicability sign "(+)" limited applicability of some groups of this type of product.

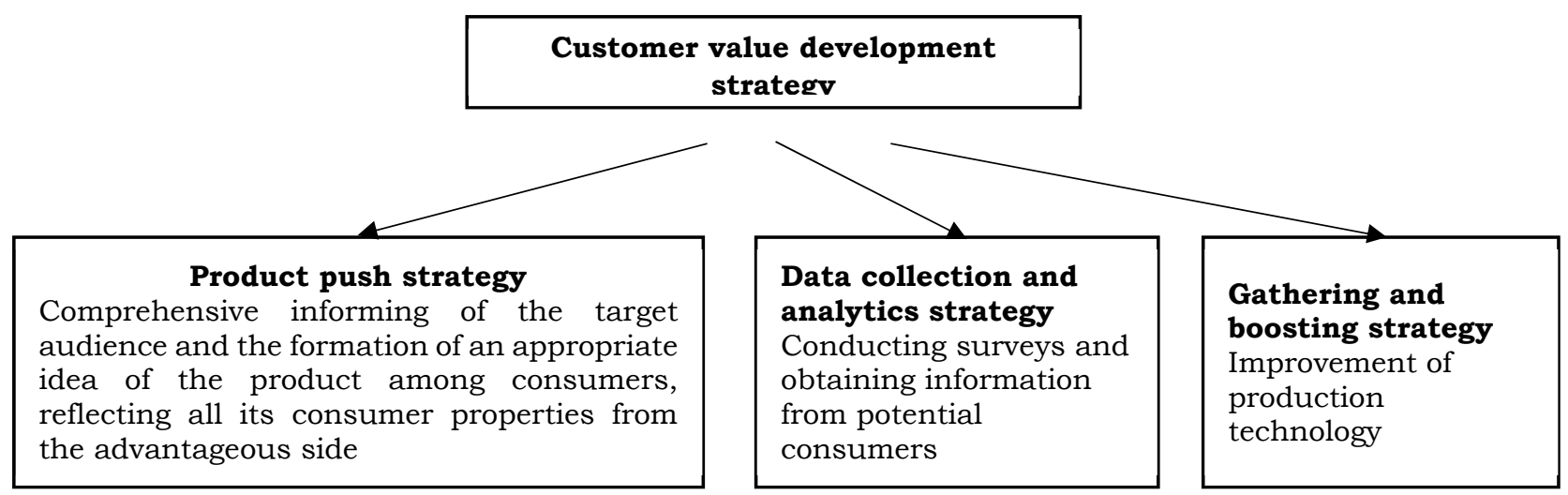

Source: compiled by the author

Figure 2 - Strategies for increasing customer value

To determine the consumer value of a product for a trade enterprise, the Kano method was 44 applied, which belongs to a non-monetary approach to assessing and analyzing the 
consumer value of a product. On the basis of my research, it is possible to form a certain dependence of the influence of factors and characteristics of a product on its quality and the degree of their significance for the consumer. The comparison results are presented in Table 2.

Table 2

\section{Significance of attributes by gradation}

\begin{tabular}{|l|l|}
\hline \multicolumn{1}{|c|}{ Attributes according to customer value } & \multicolumn{1}{c|}{$\begin{array}{c}\text { Attributes by the degree of influence on the } \\
\text { quality of the goods }\end{array}$} \\
\hline $\begin{array}{l}\text { - Updated recipe } \\
\text { - Low price }\end{array}$ & $\begin{array}{l}\text { - Low price } \\
\text { - Discount when buying a certain amount }\end{array}$ \\
$\begin{array}{l}\text { - Updated, improved packaging } \\
\text { - Updated, improved packaging } \\
\text { - External presentation }\end{array}$ & $\begin{array}{l}\text { - Updated recipe } \\
\text { - External presentation }\end{array}$ \\
\hline
\end{tabular}

Source: compiled by the author

Based on the table, it is obvious that the external presentation as a characteristic of the product is the most significant attribute in the formation of the consumer value of the products of the trade enterprise. It is also worth noting that this factor has the most intense impact on the quality of the company's goods. This factor is directly related to product quality and is an indicator of it. This means that a product improvement strategy can be used as the main strategy for increasing customer value.

This strategy is more logical and easier to justify a high price. Improvements and changes will help to further reduce consumer costs. The actions that will be taken under this strategy involve all three main attributes of customer value, which have a large impact on product quality. In the case of improving the presentation of the product, it is necessary, first of all, to find out what defects in the appearance have been identified during the entire existence of the product. This can be both damage received during transportation, and errors, and insufficient control of technologists over the preparation of products. Thus, consumer enterprises can get substandard goods on the shelves. Both of the above reasons for the appearance of substandard goods on the shelves of goods take place.

The factor of damage to goods during transportation, unloading and display of goods can be excluded due to a more thorough examination of the product upon receipt by the consumer enterprise. However, there is a risk that intermediary enterprises may turn out to be unscrupulous and, if the goods are damaged through their own fault, they will sell substandard goods at a quality price, not wanting to lose money that they would not have received if they were sold at a reduced interest rate. Unfortunately, this risk is almost impossible to exclude. In the case when mistakes and low qualification of technologists are the reason for the deterioration of the external presentation, serious measures must be taken. Firstly, it is necessary to ensure more careful supervision of the process of processing, preparation and production in general. Secondly, advanced training of technologists will allow not only to improve the quality of products, but also to improve the production processes themselves. The next factor in terms of the degree of influence on product quality is the renewal of the product recipe. $54 \%$ of respondents believe that the renewal of the recipe will lead to an increase in the consumer value of the product [16]. However, the opportunity to generate consumer interest by updating products should not be underestimated.

In other words, the excitement caused by new products in the range of offered goods, combined with the quality of these new products, will directly affect the consumer value of the product. However, this path has its own risks, as changes in the structure of some recipes and taste changes can lead to both positive and negative consumer reviews. That is why it is necessary to introduce innovations into the production process deliberately, gradually and release a new product in small batches. Trial limited editions will allow not only to assess the reaction of the end user, but also to protect the enterprise from high costs and losses in case of unsuccessful introduction of changes. Improvements and changes in packaging do not affect the quality of the line, however, for $80 \%$ of respondents, bright and memorable packaging plays an important role in making a purchase decision. Product packaging is its face, and this is the first thing the buyer will pay attention to when choosing, in addition to the price. In other words, all other things being equal, the one that is more aesthetic and noticeable among the many similar products will be chosen from the two products. In order for the improvement of packaging to somehow affect the quality of products, it is possible, in addition to the appearance, to improve the quality and tightness of the packaging. By purchasing higher quality materials, be it wrapping paper and materials for vacuum, or plastic containers, the company will increase the consumer value of the product. This is one of the most inexpensive, however, effective ways. In the course of the study, such attributes as a reduced price (the price is lower than that of a competitor) and a discount when buying a certain amount took the first places among the available factors. These factors will directly increase customer value, but this will not affect product quality in any way. 
In the first case, price reduction can only be an extreme measure applied to increase the consumer value of the product. With a decrease in price, the difference between the cost of goods and the cost of its production decreases, at the same cost. This option for increasing customer value can only be used in critical situations. For example, when a competing enterprise appeared, a significant number of consumers were lost, the enterprise dumped, thereby attracting attention to itself and making its products more attractive. Such a strategy should not be protracted, as otherwise the organization will suffer heavy losses, up to and including liquidation. A high price justification strategy is the opposite example. For example, a newly-made competitor firm sets prices for its goods lower than ours, which led to a decrease in sales volumes, and hence a decrease in income. To maintain profitability, it is necessary to maintain the price level, which means that the only way out of this situation may be to justify the cost of products and convince the consumer that it is profitable for him to purchase our product.

In conclusion, I would like to note that the choice of a strategy to increase the consumer value of a product is only behind the management of the enterprise. In order to select the correct and effective strategy, it is necessary not only to analyze the statistics of sales, profits, but also special attention must be paid to the preferences of consumers and the desired factors that they want to see in the purchased product. In today's competitive environment, customer value is one of the deciding factors in product sales. However, most enterprises in every possible way neglect the assessment of consumer demand, and then the needs and expected benefits from the acquisition, as well as the quality of the goods, decrease, thereby increasing the purchasing risks and costs of using the goods. This phenomenon adversely affects not only consumers, but also manufacturers of products. This neglect not only reduces sales, revenues and profits, but also leads to the death of the enterprise.

Analysis and assessment of customer value should become an integral procedure of every leading and successful organization in today's market. As a result, consumers will receive highquality goods, with all the necessary characteristics, and enterprises will make profit, growth and leading positions among competitors. The detailed results of the customer value assessment are presented in Table 3.

Table 3

Positive evaluation and analysis results for consumers and producers in action

\begin{tabular}{|l|l|}
\hline \multicolumn{1}{|c|}{ Manufacturing company } & \multicolumn{1}{c|}{ Consumers } \\
\hline - Profit growth; & - Reducing purchasing risks; \\
- Reducing the risks of unsold goods; & - Obtaining a quality product that meets all the \\
- Decrease in production costs; & requirements and DSTU; \\
- Entering a leading position in the market; & - Purchase of goods with the desired \\
- Obtaining advantages over competitors; & characteristics; \\
- Gaining a good reputation as a result of the & - Possibility of long-term cooperation on favorable \\
production and release of quality products & terms \\
\hline
\end{tabular}

Source: compiled by the author

Thus, consumer value can rightfully be considered one of the foundations for obtaining a quality product. Production of goods, taking into account all the desired factors and characteristics for the consumer, the basis of a quality product and the successful existence of a competitive enterprise in a market economy.

\section{Conclusion}

Based on the work done, the following conclusions can be drawn. The topic of consumer value as the basis for the quality of an enterprise's products is not considered fully studied. Currently, there is no single definition of this concept and any clear developments and programs to increase customer value. Researchers studying this topic and problem are constantly expanding not only the concept of quality, but also, considering the theory of the basis of consumer choice and value, develop ways and methods of increasing it. Based on the analysis that was carried out within the framework of the study, the following definitions of consumer value can be formed: 1) the ratio between the benefits that the client receives as a result of the purchase and use of the product and the cost of purchasing it; 2) everything that is important for the consumer in relation to the product, namely the properties and characteristics that he is willing to pay; 3) what the consumer is guided by when purchasing any kind of goods.

Quality refers to the ability of a product to meet the needs and expectations of the consumer. From the formulations of the concept of "product quality" considered in the work, it can be concluded that quality can be assessed through a quantitative measurement of the real properties of a product and a quantitative assessment of the needs that these properties must satisfy. The problem of an adequate quantitative assessment of product quality is complicated by the establishment of a single numerical characteristic and all properties that correspond to inconstant and uncertain real-life and anticipated needs.

Despite the fact that solving problems of analyzing and comparing the compliance of the objective properties of various products with the 
subjective needs of individual consumers is a difficult task of assessing quality, specialists in various fields of activity are constantly developing new methods for solving them. In the course of the study, it became clear that in determining the customer value, quality characteristics play an important role in the acquisition. The problem of assessing value lies in the absence of a unit of assessment, and also in the fact that each person has his own level of needs, which means that for each the assessment of consumer value will be different. Such an assessment can be made only conditionally.

There are three main methods for assessing value: monetary, non-monetary, synthetic (a combination of the two previous methods). Each of the methods has its own advantages and disadvantages, and the field of application and differ depending on the chosen measurement methods. To assess and analyze the consumer value of a trade enterprise, a non-monetary value assessment approach was chosen. For the study, a questionnaire was conducted using the Kano method. Out of the five selected attributes, the external presentation and bright updated packaging were noted by 80 percent of the respondents, and these characteristics also directly affect the quality of the product.

Thus, product improvement can be considered a valid strategy for increasing customer value. Thanks to the chosen value-adding strategy, the products will become of higher quality and in demand among customers. Taking into account the preferences and desires of consumers for the characteristics of the product, one can correctly choose the direction of the strategy, which will entail an increase in the perceived value. Increasing the consumer value of products is one of the most pressing and complex problems of the enterprise, however, having found a solution, the enterprise expects a rapid increase in product output, profits and the opportunity to take a leading position in the market among competitors.

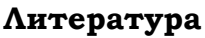

1. Babenko, V. Gas supply security model to EU consumers. The Journal of V. N. Karazin Kharkiv National University. Series: International Relations. Economics. Country Studies. Tourism. 2020. (12), $78-87$. https://doi.org/10.26565/2310-9513-2020-12-07

2. Babenko V., Sidorov V., Savin R. Activity of agroholdings in the world market of agricultural products in the context of globalization. The Journal of V. N. Karazin Kharkiv National University. Series: International Relations. Economics. Country Studies. Tourism. 2018. № 8. Pp. 101-106. https://doi.org/10.26565/23109513-2018-8-11

3. Biletska, Y., Babenko, V., Gusliev, A. Marketing studies of consumption preferences at developing dietary products. EUREKA: Social and Humanities. 2019. 5, pp. 16-21. https://doi.org/10.21303/25045571.2019 .001009

4. Byrne Patrick, Mitchell Mark. The Story of Deep Capture. 2014. URL: http://www/deepcapture-thesto1.pdf (дата звернення: 02.03.2021)

5. Davidson Steven, Harmer Martin, and Marshall Anthony. The New Age of Ecosystems. IBM Institute for Business. 2015.

6. John F., Nash Jr. Ideal Money and Asymptotically Ideal Money. 2014. URL: http:/ / sites.stat.psu.edu/ babu/nash/money.pdf (дата звернення: 29.03.2021)

7. Kosten Dmitri. Bitcoin Mission Statement. Or What Does It Mean Sharing Economy and Distributed Trust? 2015. URL: http://ssrn.com/abstract=2684256 (дата звернення: 02.03.2021)

8. Malyarets, L., Iastremska, O., Herashchenko, I., Iastremska, O., Babenko, V. Optimization of Indicators for Management of Enterprise: Finance, Production, Marketing, Personnel. Estudios de Economía Aplicada. 2021. Vol. 38-3(1), pp. 1-13. http://dx.doi.org/10.25115/eea.v38i4.4028

9. Thomas Piketty, and Goldhammer Arthur. Capital in the Twentyfirst Century. Cambridge Massachusetts: Belknap of Harvard UP, 2014. Print. 452 p.

10. Phelps J. Pyramids are Tombs. Traditional corporate structure, like the 20th century, is history. 2015. URL: http:/ / pyramidsaretombs.com/Company_Organisation/?chapter=116 (дата звернення: 01.04.2021)

11. Котмер Ф. Основы маркетинга. Перевод на русский язык: В. Б. Бобров. М., 1990.

12. Shorrocks Anthony, Davies James, and Lluberas Rodrigo. Credit Suisse Global Wealth Databook 2013. URL: $\quad$ https:// publications.creditsuisse.com/tasks/render/file/?fileID=1949208D-E59A-F2D96D0361266E44A2F8 (дата звернення: 29.03.2021)

13. Noyola E. Ethereum, tokens \& smart contracts. Notes on getting started. New York: Wiley, 2017.216 p.

14. Shermin V. Disrupting governance with blockchains and smart contracts // Review of Financial Economics, 2017. Vol. 25 (5). P. 499 - 509.

15. Stoilov R. Solidity Smart Contracts: Build DApps in Ethereum Blockchain. New York: Routledge, 2019. $95 \mathrm{p}$.

\section{References}

1. Babenko, V. (2020). Gas supply security model to EU consumers. The Journal of V. N. Karazin Kharkiv National University. Series: International Relations. Economics. Country Studies. Tourism, (12), 78-87. https://doi.org/ 10.26565/2310-9513-2020-12-07 
2. Babenko V., Sidorov V., Savin R. ( 2018). Activity of agroholdings in the world market of agricultural products in the context of globalization. The Journal of V. N. Karazin Kharkiv National University. Series: International Relations. Economics. Country Studies. Tourism. № 8. Pp. 101-106. https://doi.org/10.26565/2310-9513-2018-8-11

3. Biletska, Y., Babenko, V., Gusliev, A. (2019). Marketing studies of consumption preferences at developing dietary products. EUREKA: Social and Humanities, 5, pp. 16-21. https://doi.org/10.21303/25045571.2019.001009

4. Byrne Patrick, Mitchell Mark. (2014). The Story of Deep Capture. URL: http://www/deepcapture-thesto1.pdf

5. Davidson Steven, Harmer Martin, and Marshall Anthony. (2015). The New Age of Ecosystems. IBM Institute for Business. Value, 16.

6. John F., Nash Jr. (2014). Ideal Money and Asymptotically Ideal Money. URL: http:/ / sites.stat.psu.edu/ babu/nash/money.pdf

7. Kosten Dmitri (2015). Bitcoin Mission Statement. Or What Does It Mean Sharing Economy and Distributed Trust?. URL: http://ssrn.com/abstract $=2684256$

8. Malyarets, L., Iastremska, O., Herashchenko, I., Iastremska, O., Babenko, V. (2021). Optimization of Indicators for Management of Enterprise: Finance, Production, Marketing, Personnel. Estudios de Economía Aplicada, Vol. 38-3(1), pp. 1-13. http://dx.doi.org/10.25115/eea.v38i4.4028

9. Thomas Piketty, and Goldhammer Arthur (2014). Capital in the Twentyfirst Century. Cambridge Massachusetts: Belknap of Harvard UP. Print. 452p.

10. Phelps J. (2015). Pyramids are Tombs. Traditional corporate structure, like the 20th century, is history. URL: http:// pyramidsaretombs.com/Company_Organisation/?chapter=116

11. Philip Kotler (1990). Marketing Essentials, M.

12. Shorrocks Anthony, Davies James, and Lluberas Rodrigoredit Suisse. (2013). Global Wealth Databook. URL: https:// publications.creditsuisse.com/tasks/render/file/?fileID=1949208D-E59A-F2D96D0361266E44A2F8

13. Noyola E. (2017). Ethereum, tokens \& smart contracts. Notes on getting started. New York: Wiley. 216 p.

14. Shermin V. (2017). Disrupting governance with blockchains and smart contracts // Review of Financial Economics, Vol. 25 (5). P. 499 - 509.

15. Stoilov R. (2019). Solidity Smart Contracts: Build DApps in Ethereum Blockchain. New York: Routledge, 95 p.

16. Ukrainian Institute of the Future. Ukraine $2030 \mathrm{E}$ is a country with a developed digital economy. URL: https://strategy.uifuture.org/kraina-z-rozvinutoyu-cifrovoyu-ekonomikoyu.html\#summary

\section{СПОЖИВЧА ЦІННІСТЬ ТОВАРІВ В УМОВАХ ЦИФРОВІЗАЦІЇ ЕКОНОМІКИ}

Бабенко Віталіна Охексіївна, доктор економічних наук, кандидат технічних наук, професор, кафедра міжнародної електронної комерції та готельно-ресторанної справи, Харківський національний університет імені В. Н. Каразіна, майдан Свободи, 4, м. Харків, 61022, Україна, e-mail: vitalinababenko@karazin.ua, ORCID: https://orcid.org/0000-0002-4816-4579, Scopus Author ID: 56658371300

Федорова Ганна Юріївна, викладач, Харківський національний університет імені В. Н. Каразіна, пц. Свободи, 4, м. Харків, Україна, 61022, e-mail: g.y.fedorova@karazin.ua

Походенко Борис Омексійович, викладач, Харківський національний університет імені В. Н. Каразіна, майдан Свободи, 4, м. Харків, 61022, Україна, e-mail: boris.pokhodenko@karazin.ua, ORCID: https://orcid.org/0000-0002-9995-7077

Об'єктом дослідження є споживча цінність товару як основа якості продукції підприємства в умовах цифровізації економіки. Мета роботи - на основі дослідження та оцінки споживчої цінності товару як основи якості продукції сформувати комплекс рекомендацій щодо підвищення споживчої цінності товару. За основу методів дослідження розглянуті три основні підходи: монетарний, немонетарний і синтетичний. У процесі дослідження розглядалися методологічні засади формування споживчої цінності продукції, досліджено вплив споживчої цінності на якість продукції, проаналізовано споживча цінності продукції в умовах цифровізації економіки. В результаті дослідження були розроблені практичні рекомендації і заходи щодо підвищення споживчої цінності продукції в умовах цифровізації економіки. Результати дослідження полягає в розробці комплексу заходів щодо вдосконалення виробничого процесу підприємства з метою збільшення якості продукції за допомогою збільшення споживчої цінності в умовах цифровізації економіки. Перспективи дослідження: планується глибше вивчити проблеми взаємодії якості товару і споживчої цінності, розробити комплекс і програму по збільшенню споживчої цінності продукції в умовах цифровізації економіки.

КАючові слова: споживча цінність, цифровизация економіки, суб'єкти ринку, підприємство торгівці, споживчий ринок.

\section{ПОТРЕБИТЕАЬСКАЯ ЦЕННОСТЬ ТОВАРОВ В УСАОВИЯХ ЦИФРОВИЗАЦИИ ЭКОНОМИКИ}

Бабенко Витамина Амексеевна, доктор экономических наук, кандидат технических наук, профессор, Харьковский национальный университет имени В. Н. Каразина, пл. Свободы, 4, г. Харьков, 61022, Украина; e-mail: vitalinababenko@karazin.ua; ORCID: https://orcid.org/0000-0002-4816-4579; Scopus Author ID: 56658371300 
Федорова Анна юрьевна, преподаватель, Харьковский национальный университет имени В. Н. Каразина, пл. Свободы, 4, г. Харьков, Украина, 61022, e-mail: g.y.fedorova@karazin.ua

Походенко Борис Ахексеевич, преподаватель, Харьковский национальный университет имени В. Н. Каразина, пц. Свободы, 4, г. Харьков, Украина, 61022, e-mail: boris.pokhodenko@karazin.ua, ORCID: https://orcid.org/0000-0002-9995-7077

Объектом исследования является потребительская ценность товара как основа качества продукции предприятия в условиях цифровизации экономики. Цель работы - на основе исследования и оценки потребительской ценности товара как основы качества продукции сформировать комплекс рекомендаций по повышению потребительской ценности товара. За основу методов исследования рассмотрены три основных подхода: монетарный, немонетарный и синтетический. В процессе исследования рассматривались методологические основы формирования потребительской ценности продукции, исследовано влияние потребительской ценности на качество продукции, проанализирована потребительская ценности продукции в условиях цифровизации экономики. В результате исследования были разработаны практические рекомендации и мероприятия по повышению потребительской ценности продукции в условиях цифровизации экономики. Результаты исследования заключается в разработке комплекса мероприятий по усовершенствованию производственного процесса предприятия в целях увеличения качества продукции посредством увеличения потребительской ценности в условиях цифровизации экономики. Перспективы исследования: планируется глубже изучить проблемы взаимодействия качества товара и потребительской ценности, разработать комплекс и программу по увеличению потребительской ценности продукции в условиях цифровизации экономики.

КАючевые слова: потребительская ценность, цифровизация экономики, субъекты рынка, предприятие торговци, потребитемьский рынок.

Статтю отримано 25 мютого 2021 р. 